\title{
Pelatihan perencanaan pembangunan bagi aparatur desa di Desa Baumata Utara Kecamatan Taebenu Kabupaten Kupang
}

\author{
Nursalam ${ }^{1^{*}}$ \\ ${ }^{1}$ Administrasi Negara, Fisip, Universitas Nusa Cendana, Kupang
}

nursalamjeppu@yahoo.com

\begin{abstract}
Village development planning is a routine activity carried out in order to carry out development. Activities that involve many parties (stakeholders), namely all members of the community and village officials need very good planning. The capacity of village officials is very much needed in order to anticipate and translate various development programs according to the demands and needs of the community by utilizing the potential and resources available in the village. The fact indicate that the planning capacity of the apparatus is still not optimal, the indication is that the Proposed list of village development activity plans (DURK-Desa) does not reflect the potential and needs of the village. Planning training for village apparatus aims to provide planning insights so that in the end they can carry out planning functions effectively. The method used in development planning training for village apparatus is the education method, in which village apparatus are given training to be able to apply village development planning analysis techniques with courses; (1) analysis of village potential; (2) SWOT analysis and; (3) formulation of alternative proposals for village development planning. To determine the success of the training, a success evaluation method was made, namely the method; (1) program evaluation; (2) evaluation of results and; (3) final evaluation of activities. The based on the evaluation of planning training, village apparatus have been able to carry out various activities, including; carry out a simple analysis of the potential for village development; SWOT analysis on village development planning and; able to formulate various alternative proposals for village development programs / projects based on the potential and problems faced by the community.
\end{abstract}

Keywords: development planning; apparatus competence; planning capacity

\begin{abstract}
Abstrak
Perencanaan pembangunan desa merupakan aktifitas rutin yang dilakukan dalam rangka melaksanakan pembangunan. Kegiatan yang melibatkan banyak pihak (stakeholders) yaitu seluruh warga masyarakat dan aparat desa membutuhkan perencanaan yang sangat baik. Kapasitas aparat desa sangat diperlukan dalam rangka mengantisipasi dan menerjemahkan berbagai program pembangunan sesuai tuntutan dan kebutuhan masyarakat dengan memanfaatkan potensi dan sumber daya yang tersedia di desa. Kondisi empirik menunjukkan bahwa kapasitas perencanaan yang dimiliki oleh aparat masih belum optimal, indikasinya adalah Daftar Usulan Rencana Kegiatan Pembangunan Desa (DURK-Desa) belum mencerminkan potensi dan kebutuhan desa. Pelatihan Perencanaan bagi aparat desa bertujuan memberikan wawasan perencanaan sehingga pada akhirnya dapat melakukan fungsi perencanaan secara efektif. Metode yang digunakan dalam pelatihan perencanaan pembangunan bagi aparat desa ini adalah metode Pendidikan yaitu aparat desa diberikan pelatihan untuk mampu mengaplikasi
\end{abstract}


teknik analisis perencanaan pembangunan desa dengan materi; (1) analisis potensi desa; (2) analisis SWOT dan; (3) perumusan alternatif penyusunan perencanaan pembangunan desa. Untuk mengetahui keberhasilan pelatihan maka dibuat metode evaluasi keberhasilan, yaitu metode; (1) evaluasi program; (2) evaluasi hasil dan; (3) evaluasi akhir kegiatan. Berdasarkan evaluasi terhadap pelatihan perencanaan, aparat desa telah mampu melakukan berbagai aktifitas antara lain; melakukan analisis sederhana mengenai potensi pembangunan desa; analisis SWOT tentang perencanaan pembangunan desa dan; mampu merumuskan berbagai alternatif usulan program/proyek pembangunan desa berdasarkan potensi dan permasalahan yang dihadapi oleh masyarakat.

Kata Kunci: perencanaan pembangunan; kompetensi aparat; kapasitas perencanaan

\section{PENDAHULUAN}

Pembangunan pada hakikatnya adalah suatu proses dan usaha yang dilakukan secara sistematis untuk mencapai situasi atau kondisi yang lebih baik dari kondisi sebelumnya. Kartasasmita (1997) mengemukakan bahwa pembangunan sebagai "suatu proses perubahan ke arah yang lebih baik melalui upaya yang dilakukan secara terencana". Sedangkan Ndraha (1994) menyatakan bahwa pembangunan bagi masyarakat desa berkaitan dengan kemampuan masyarakat untuk berkembang secara mandiri melalui kemampuan untuk mengidentifikasi kebutuhan dan masalah-masalah yang dihadapi, menyusun usaha untuk memenuhi kebutuhan serta memecahkan masalah.

Berkaitan dengan upaya pembangunan desa terdapat beberapa masalah yang seringkali ditemui yang memerlukan perhatian serius dalam perumusan perencanaan pembangunan desa. Menurut Sulistio (2009), permasalahan tersebut antara lain: (a) terbatasnya ketersediaan dan kualitas sumberdaya manusia yang baik dan profesional; (b) terbatasnya ketersediaan sumber-sumber pembiayaan yang memadai, baik yang berasal dari kemampuan desa itu sendiri (internal) maupun sumber dana dari luar (eksternal); (c) belum tersusunnya kelembagaan sosial-ekonomi yang mampu berperan secara efektif; (d) belum terbangunnya sistem dan regulasi yang jelas dan tegas dan; (e) kurangnya kreativitas dan partisipasi masyarakat secara lebih kritis dan rasional.

Perencanaan pembangunan desa merupakan unsur pokok dalam manajemen pembangunan desa, mengingat kebutuhan pembangunan di desa lebih besar dari pada sumber daya yang tersedia. Melalui perencanaan ingin dirumuskan kegiatan pembangunan desa yang secara efisien dan efektif dapat memberikan hasil yang optimal dalam memanfaatkan sumber daya yang tersedia dan mengembangkan potensi yang ada (Kartasasmita, 1997).

Wujud perencanaan pembangunan yang perlu mendapatkan perhatian pada level pemerintahan desa adalah penyusunan dokumen rencana pembangunan desa, pelaksanaan evaluasi kinerja dan pemantauan program/proyek pembangunan desa, serta pengelolaan sistem informasi untuk mendukung perencanaan pembangunan desa. Syahwier (2011) perencanaan pembangunan desa memerlukan kewenangan antara lain: merencanakan dan mengorganisasi sumber daya desa, menyiapkan sumber pembiayaan pembangunan desa, dan melakukan optimalisasi sumber daya ekonomi desa. Pilar 
tersebut, membutuhkan kemampuan (kapabilitas) aparat desa sebagai syarat untuk mencapai efektivitas dalam perencanaan. Melalui sumber daya aparatur desa, mereka diharapkan melakukan perubahan yang transformatif dan inovatif guna menyelesaikan kompleksitas beragam problem pembangunan yang dihadapi oleh desa.

Berdasarkan fakta menunjukkan bahwa keberhasilan perencanaan pembangunan desa ditentukan oleh kemampuan aparat dalam memahami potensi, permasalahan, dan kebutuhan desa. Menurut Chambers (1997) dan Supeno (2011) sumber daya manusia yang terdapat pada kelembagaan desa sangat berperan dalam merumuskan permasalahan dan potensi suatu desa. Mengacu kepada pandangan tersebut diatas, maka aspek kemampuan aparat desa menjadi salah satu syarat utama yang diperlukan bagi efektivitas perencanaan pembangunan di desa.

Kapabilitas mengacu kepada konsep tentang kompetensi yang harus dimiliki dalam melaksanakan tugas dan fungsinya sebagai aparat. Menurut Spencer dan Spencer (1993), kompetensi sebagai karakteristik dasar seseorang berkaitan dengan kinerja yang kriterianya efektif dan unggul dalam suatu pekerjaan atau situasi tertentu. Sedangkan Sofo (1999) memaknai kompetensi terdiri atas keterampilan, pengetahuan, dan sikap.

Sementara Robbins (2003) mengemukakan kompetensi sebagai "ability "yaitu kapasitas seseorang individu untuk mengerjakan berbagai tugas dalam suatu pekerjaan. Aparatur pemerintah desa yang memiliki kemampuan perencanaan adalah aparat yang mampu menerapkan fungsi perencanaan pembangunan desa, sehingga dapat melakukan pelayanan kepada masyarakat dengan baik, yang pada akhirnya mampu menumbuhkan prakarsa dan partisipasi masyarakat. Kemampuan perencanaan diperlukan untuk menentukan pencapaian tujuan pembangunan. Menurut Ndraha (1994), dilihat dari aspek administratif, kemampuan untuk mencapai tujuan yang diinginkan dapat dilalui dengan sistem-sistem pendukung pembangunan.

Aparatur desa dalam melaksanakan perencanaan pembangunan juga harus memperhatikan prinsip-prinsip, antara lain: (1) accountable, rencana yang dibuat harus dapat dipertanggungjawabkan kepada masyarakat; (2) transparent, dalam membuat rencana dilakukan secara terbuka dan diketahui oleh masyarakat; (3) acceptable, pilihan kegiatan berdasarkan musyawarah sehingga memperoleh dukungan masyarakat; (4) sustainable, produk rencana dan implementasinya dapat memberikan manfaat kepada masyarakat secara berkelanjutan.

Selain dari pada itu penyelenggaraan pemerintahan dan pembangunan desa juga dituntut untuk mengakomodasi aspirasi masyarakat, mewujudkan peran aktif serta bertanggungjawab terhadap perkembangan kehidupan bersama sebagai sesama warga desa. Hal ini telah ditegaskan dalam pengaturan mengenai desa yaitu PP No 72 tahun 2005. Prinsip dasar sebagai landasan pemikiran pengaturan mengenai desa yaitu; keanekaragaman, partisipasi, otonomi asli, demokratisasi, dan pemberdayaan masyarakat.

Kegiatan Perencanaan pembangunan desa selanjutnya diatur melalui mekanisme Musrenbang yang merupakan forum publik perencanaan (program) yang 
diselenggarakan oleh lembaga publik yaitu pemerintah desa/kelurahan, kecamatan, pemerintah kota/kabupaten bekerjasama dengan warga dan para pemangku kepentingan. Penyelenggaraan musrenbang merupakan salah satu tugas pemerintah untuk menyelenggarakan urusan pemerintahan, pembangunan dan kemasyarakatan. Pembangunan tidak akan bergerak maju apabila salah satu saja dari tiga komponen tata pemerintahan (pemerintah, masyarakat, swasta) tidak berperan atau berfungsi. Karena itu, musrenbang juga merupakan forum pendidikan warga agar menjadi bagian aktif dari tatapemerintahan dan pembangunan.

Musrenbang sebenarnya secara tidak langsung akan memberikan pembelajaran kepada masyarakat untuk mengelola program dan dana yang terkumpul dari diri mereka yang telah diserahkan kepada negara dengan membayar pajak, retribusi dan pungutan lain yang sah, sehingga masyarakat mampu untuk merencanakan dan melaksanakan program kegiatan berdasarkan kebutuhan riil.

Proses pembangunan semestinya menempatkan masyarakat sebagai pelaku utama, artinya pemerintah tidak lagi sebagai provider dan pelaksana, melainkan lebih berperan sebagai fasilitator dan katalisator. Masyarakat harus terlibat untuk memecahkan persoalan dan memenuhi kebutuhannya dari mulai proses identifikasi masalah, perencanaan, pelaksanaan dan monitoring dan evaluasi. Pada proses perencanaan, ruang masyarakat untuk terlibat adalah pada mekanisme musrenbang.

Adapun mekanisme tahapan Musrenbang desa adalah; (a) tahap persiapan; (b) tahap pelaksanaan dan; (c) tahap pasca pelaksanaan (Permendagri Nomor 66 Tahun 2007 tentang Perencanaan Desa)

\section{Tahap Persiapan}

Tahap persiapan dilaksanakan paling lambat minggu ke IV bulan Januari, dengan kegiatan; (1) pembentukan Tim Penyelenggara Musyawarah (TPM) terdiri dari 3-5 orang ditetapkan denga SK Kepala Desa. TPM bertugas mengorganisir keseluruhan proses musrenbang dari tahap persiapan/pra musrenbang, pelaksanaan sampai dengan tahap pasca pelaksanaan musrenbang. Karena hasil musrenbang ini akan dijadikan dasar penyusunan RKP Desa maka nantinya anggota TPM juga dilibatkan sebagai bagian dari Tim Penyusun RKP Desa. Ketua TPM biasanya Sekretaris Desa yang juga otomatis karena jabatannya menjadi ketua Tim Penyusun RKPDesa. Sedangkan Kepala Desa sebagai pelindung dan pembinan TPM; (2) menyusun jadwal dan agenda pelaksanaan musenbangdesa serta menginformasikan kepada masyarakat luas dan para pemangku kepentingan; (3) merangkum berita acara musrenbangdes dan menyusun laporan pelaksanaan musrenbangdes dilengkapi; berita acara, daftar hadir, dokumentasi, dan rekapitulasi daftar usulan program dan kegiatan yang harus disampakan ketingkat kecamatan; memastikan pelaksanaan musrenbang berjalan sebagaimana mestinya. Bukan hanya sebagai acara seremonial, atau parade pidato tetapi harus benar-benar memberi ruang dan waktu bagi musyawarah warga yang partisipatip dan berkualitas. TPM harus mampu menjadi pemandu musyawarah yang baik. 


\section{Tahap Pelaksanaan}

Pada tahap pelaksanaan kegiatan-kegiatan yang dilaksanakan adalah; (1) pembukaan oleh Kepala Desa (singkat paling lama 5-10 menit); (2) penjelasan teknis pelaksanaan musyawarah, pembacaan agenda dan tata-tertib musrenbang desa. (5-7 menit); (3) pemaparan-pemaparan dari Kepala Desa tentang evaluasi pelaksanaan RKP Desa tahun sebelumnya, Camat atau aparat kecamatan yang mewakili (kasi pemberdayaan masyarakat dan desa) menyampaikan perkiraan pagu indikatif desa dan pagu indikatif wilayah kecamatan serta pembangunan sektoral dari kabupaten/provinsi yang akan dilaksanakan di desa pada tahun tersebut, dan konsep kebijakan pembangunan wilayah kecamatan (misalnya kerjasama antardesa). Bagian akhir dari pemaparan dibuka tanggapan-tanggapan dari peserta musyawarah. Pada sesi ini pemaparan dan tanggapan paling lama 30 menit. Penting setiap sesi dibatasi waktu karena bukan parade pidato. Berikan waktu yang luas untuk sesi musyawarah; (4) musyawarah Rencana Pembangunan Desa (Musrenbangdes), diberikan waktu seluas-luasnya pada sesi ini, setidaknya 90 menit. Yang dimusyawarahkan intinya yaitu ; Perumusan prioritas masalah dan prioritas usulan kegiatan. Menyepaksti nama-nama dari peserta musyawarah sebagai delegasi desa dalam forum musrenbang kecamatan untuk memperjuangkan usulan desa. Tim/ delegasi terdiri dari 3-5 sekurang-kurangnya 30\% dari unsur perempuan; (5) pembacaan berita acara musrenbangdes dan penndatangan oleh wakil peserta dan pembacaan nama-nama peserta yang menjadi delegasi desa; (6) penutupan oleh Kepala Desa.

\section{Tahap Pasca Pelaksanaan}

Pada tahap pasca pelaksanaan kegiatan yang dilakukan oleh TPM adalah penyusunan laporan yang akan menghasilkan format yang akan dilaporkan ke tingkat kecamatan, format tersebut adalah; (1) berita acara Musrenbang Desa; (2) surat mandat Musrenbang Desa; (3) format Prioritas masalah Musrenbang; (4) format prioritas kegiatan Musrenbang dan; (5) format daftar usulan Musrenbang

Secara empirik hasil perencanaan pembangunan di desa Baumata Utara Kecamatan Taebenu Kabupaten Kupang, belum efektif, fenomena tentang ketidakefektifan ini dapat dilihat dari Daftar Usulan Rencana Kegiatan Pembangunan Desa (DURK-Desa) belum mencerminkan potensi (kemampuan) dan kebutuhan desa. DURKP- Desa adalah daftar yang merupakan usulan kegiatan pembangunan Desa yang menggunakan dana yang sudah jelas sumbernya baik dari APBN, APBD (Provinsi, Kabupaten/Kota), APB Desa, Swadaya dan Kerjasama dengan Pihak ketiga (Permendagri Nomor 66 Tahun 2007). Menurut pengamatan Penulis hal ini terkait dengan keterbatasan kemampuan aparatur desa dalam melakukan perencanaan pembangunan desa.

Berdasarkan fakta ini, maka dalam rangka meningkatkan kapasitas aparat diperlukan pelatihan untuk menambah wawasan perencanaan pembangunan bagi mereka. Pelatihan bertujuan untuk: (1) memberikan kemampuan kepada aparat desa Baumata Utara kecamatan Taebenu kabupaten Kupang melakukan analisis potensi sumber daya desa: (2) memberikan kemampuan kepada aparat desa Baumata Utara melakukan 
analisis SWOT (Kelemahan, kekuatan, peluang, dan ancaman) program/proyek pembangunan desa dan; (3) memberikan kemampuan aparat desa Baumata Utara merumuskan alternatif rencana pembangunan desa yang berbasis kebutuhan masyarakat.

\section{METODE PELAKSANAAN}

Sesuai dengan uraian permasalahan mitra yang telah dikemukakan pada Bab I, metode kegiatan yang dilaksanakan dilakukan dengan tahapan sebagai berikut:

a. Tahap Persiapan Persiapan, meliputi; (1) mengurus perijinan pada instansi terkait;( 2) menyiapkan tempat untuk pelatihan; (3) menyiapkan alat-alat pendukung dalam pelaksanaan pelatihan seperti banner, sound system dan LCD; (4) undangan untuk peserta pelatihan; 5) Pembuatan power point materi pelatihan perencanaan; (5) pencetakan format-format pelatihan.

b. Tahap pelaksanaan, pada tahap pelaksanaan, metode yang ditawarkan melalui kegiatan pelatihan adalah memperkuat kapabilitas aparat desa melalui materi kegiatan pelatihan dan evaluasi keberhasilan pelatihan, yaitu;

1. Materi Kegiatan

Terdapat beberapa kegiatan yang akan dilaksanakan berkaitan dengan program ini yaitu, memberikan pelatihan perencanaan pembangunan desa, materinya antara lain:

a. Analisis potensi sumber daya desa,

b. Analisis SWOT perencanaan pembangunan desa,

c. Merumuskan alternatif perencanaan pembangunan desa yang berbasis kebutuhan masyarakat.

Agar kegiatan ini efektif, diperlukan komunikasi yang intensif antara pelaksana dan kelompok sasaran, sehingga mereka dapat memahami, menguasai dan menerapkan hasil pembelajaran perencanaan pemerintahan desa.

2. Tahap Evaluasi

Evaluasi terhadap keberhasilan kegiatan dapat diukur dari:

Evaluasi program, indikatornya adalah:

a. Target peserta pelatihan minimal $75 \%$ dari yang ditetapkan.

b. Kehadiran peserta minimal $75 \%$ dari seluruh sesi pelatihan.

c. Tersedianya juklak/juknis pelatihan

d. Ketepatan waktu pelatihan sesuai dengan rencana.

e. Ketersediaan bahan-bahan pendukung seperti daftar hadir peserta, panitia, dan instruktur; ketersediaan materi-materi pelatihan; ketersediaan perlengkapan pelatihan misalnya in fokus, ATK dan sebagainya.

Evaluasi Hasil, indikatornya adalah:

a. Minimal $75 \%$ peserta memahami dan mampu menganalis potensi sumber daya desa.

b. Minimal $75 \%$ peserta memahami dan mampu melakukan analisis SWOT perencanaan pembangunan desa. 
c. Minimal $75 \%$ peserta memahami dan merumuskan alternatif rencana desa yang berbasis kebutuhan masyarakat.

\section{Evaluasi akhir kegiatan}

Hasil akhir yang diharapkan adalah:

a. Aparatur desa dapat melakukan analisis potensi sumber daya desa.

b. Aparatur desa dapat melakukan analisis SWOT perencanaan pembangunan desa.

c. Aparatur desa dapat dan merumuskan alternatif rencana desa yang berbasis kebutuhan masyarakat.

3. Tahap Pelaporan,

Tahapan selanjutnya adalah pembuatan laporan awal. Pembuatan laporan awal disesuaikan dengan hasil yang telah dicapai selama melakukan pelatihan terhadap perencanaan bagi aparat desa Baumata Utara.

\section{HASIL DAN PEMBAHASAN}

Kegiatan pengabdian ini dilaksanakan dalam bentuk pelatihan perencanaan bagi aparat desa di desa Baumata Utara, dalam pelatihan dilakukan dengan metode ceramah dan simulasi yang dilakukan oleh instruktur dari tim PPM Fisip undana, setelah instruktur menyampaikan materinya lalu diberikan kesempatan kepada para peserta untuk bertanya dan mensimulasikan kegiatan pelatihan. Kegiatan terakhir dilakukan diskusi kelompok dan simulasi untuk memecahkan suatu masalah perencanaan yang biasanya dihadapi oleh aparat dalam merumuskan usulan kegiatan pembangunan desa. Adapun gambaran tentang pelaksanaan pelatihan perencanaan pembangunan bagi aparat desa meliputi:

\subsection{Menganalisis potensi desa}

Menurut Maschab (2013), potensi desa adalah segenap sumber daya alam dan sumber daya manusia yang dimiliki desa sebagai modal dasar yang perlu dikelola dan dikembangkan bagi kelangsungan dan perkembangan desa. Potensi desa sangat penting untuk dianalisis agar potensi yang terdapat dalam desa dapat dianalisis menjadi sumber informasi dalam kegiatan penyusunan perencanaan pembangunan desa.

Potensi desa meliputi potensi fisik dan non fisik, yaitu (1) sumber daya alam yang dimiliki desa Baumata Utara seperti lahan kosong, sungai, sawah,perkebunan, dan hutan; (2) Potensi sumber daya manusia yang dimiliki desa Baumata Utara adalah pegawai desa, kader kesehatan,kader pertanian, dan tersedianya SDM yang memadai ini bisa dilihat dari tingkat pendidikan di atas rata-rata adalah SMP/SMA; (3) sumber daya sosial, potensi sumber daya sosial yang dimiliki desa Baumata Utara adalah lembaga-lembaga yang pada dimasyarakat desa seperti LPM, Gapoktan, Kelompok doa, Arisan, Kelompok Simpan Pinjam, Posyandu, Karang Taruna, dan lain-lain potensi; (4) potensi sumber daya ekonomi Desa Baumata Utara meliputi; Lahan Pertanian, Perkebunan, Peralatanperalatan seperti tenda dan kursi untuk acara kegiatan desa dan kegiatan keluarga. 
Pada kegiaatan pelatihan, aparat desa diberikan pengetahuan tentang potensi desa sebagai dasar dalam penyusunan Rencana Pembangunan Jangka Menengah Desa (RPJM-Desa) dan Rencana kegiatan Pembangunan Desa (RKP-Desa).

Berdasarkan penjelasan naras sumber/instruktur pelatihan bahwa pengetahuan tentang potensi dan permasalahan yang dihadapi oleh desa dapat digunakan untuk menghasilkan informasi; (a) masalah dan potensi dari potret Desa; (b) masalah dan potensi dari kalender musim, dan (c) bagan Kelembagaan. Selanjutnya berdasarkan hasil pengkajian tentang potensi dan masalah juga akan menghasilkan (a) penentuan peringkat masalah; (b) tindakan pemecahan masalah; dan (c) penentuan peringkat tindakan.

\subsection{Analisis SWOT Untuk Perencanaan Pembangunan Desa}

Menurut Sjafrizal (2015) analisis SWOT merupakan teknik identifikasi berbagai faktor dan unsur penentu pembangunan suatu instansi secara sistimatis. Istilah SWOT merupakan singkatan dari empat kata, yaitu; strength (kekuatan), weaknesses (kelemahan), opportunities (peluang), dan threat (ancaman). Teknik analisis SWOT bertujuan untuk melakukan evaluasi kondisi lingkup kegiatan bersangkutan yang selanjutnya dapat digunakan untuk merumuskan strategi pembangunan.

Keempat unsur SWOT tersebut dapat pula dikelompokkan atas dua, yaitu faktor internal dan faktor eksternal. Unsur kekuatan dan kelemahan merupakan faktor internal yang berasal dari dalam suatu lingkungan tugas institusi tertentu. Sedangkan unsur peluang dan ancaman merupakan faktor eksternal yang berasal dari luar lingkup tugas tertentu tetapi berpengaruh terhadap masa depan institusi tertentu.

Instruktur/nara sumber yang menyampaikan materi memberikan penjelasan tentang manfaat analisis SWOT pada kegiatan perencanaan. Menurut mereka Analisis SWOT merupakan salah satu teknik analisis, metode yang dapat menghasilkan rencana strategis (Renstra), dalam konteks perencanaan pembangunan renstra merupakan salah tugas pokok dalam perencanaan pembangunan desa, berdasarkan peraturan perundangundang setiap desa harus memiliki RPJM-Desa sebagai pedoman dalam penyusunan RKP-Desa.

Secara spesifik ada dua manfaat penggunaan analisis SWOT dalam penyusunan perencanaan pembangunan desa, yaitu: (1) dengan menggunakan analisis SWOT, pembahasan tentang kondisi umum desa, baik yang menyangkut tentang kekuatan, kelemahan, peluang dan ancaman akan lebih tajam dan terarah kepada hal-hal yang berkaitan langsung dengan penyusunan perencanaan desa; (2) dengan penggunaan analisis SWOT dapat dirumuskan strategi (RPJM-Desa) sesuai dengan kondisi desa.

Analisis SWOT yang dibahas dalam pelatihan memberikan pengetahuan kepada para peserta pelatihan tentang bagaimana strategi pembangunan desa yang sesuai potensi 
dan permasalahan desa. Berdasarkan pemahaman mereka tentang analisis SWOT, mereka kemudian dapat melakukan analisis faktor strategis, yaitu melakukan analisis secara mendalam tentang faktor internal dan faktor eksternal sehingga menghasilkan rumusan strategi perencanaan pembangunan desa. Berkaitan dengan perumusan strategi maka diperlukan pembuatan matriks SWOT yaitu dengan cara menggunakan hasil analisis faktor internal dan eksternal. Selain itu agar analisis strategis tersebut lebih baik dan terukur maka diperlukan penggunaan skor dan bobot terhadap penilaian untuk masing-masing unsur, baik unsur eksternal maupun internal.

Berdasarkan hasil simulasi yang dilakukan oleh para peserta pelatihan diketahui bahwa faktor-faktor strategis tersebut adalah mempunyai nilai (skor kali bobot) relatif tinggi yang meliputi kekuatan, kelemahan, peluang dan ancaman. Penjelasan lebih lanjut yang diperoleh para peserta pelatihan bahwa penggunaan analisis SWOT dalam perencanaan memang mengandung kelebihan dan kekurangan. Kelebihannya adalah bahwa analisis SWOT dapat menghasilkan sejumlah informasi untuk kepentingan strategi, karena diketahui faktor kekuatan, kelemahan, peluang, dan ancaman.

Penggunaan metode analisis SWOT dalam penyusunan perencanaan pembangunan desa memiliki juga kelemahan, yaitu; (1) tingkat subjektivitasnya tinggi, yang dilakukan oleh perencana dalam melakukan analisis, terutama dalam menentukan kekuatan, kelemahan, peluang, dan ancaman, namun subjektivitas dapat diminimalkan dengan dukungan data kuantitatif dalam menentukan kekuatan, kelemahan, peluang dan ancaman; (2) kelemahan lain penggunaan analisis SWOT berkaitan dengan penganggaran.

Teknik analisis SWOT belum dapat dilakukan secara terkait dan sistimatis dengan perumusan anggaran yang diperlukan dalam mewujudkan strategi dan kebijakan pembangunan desa.

\subsection{Merumuskan alternatif rencana pembangunan desa yang berbasis kebutuhan masyarakat}

Materi terakhir yang disampaikan kepada peserta pelatihan perencanaan adalah penyampaian tentang bagaimana merumuskan alternatif usulan rencana pembangunan desa.

Alternatif usulan rencana pembangunan desa pada akhirnya akan menghasilkan Rencana Kerja Pembangunan Desa yang selanjutnya disingkat RKP-Desa adalah dokumen perencanaan untuk periode 1 (satu) tahun yang merupakan penjabaran dari RPJM-Desa, memuat rancangan kerangka ekonomi desa, dengan mempertimbangkan kerangka pendanaan yang dimutahirkan, program prioritas pembangunan desa, rencana kerja dan pendanaan serta prakiraan maju, baik yang dilaksanakan langsung oleh pemerintah desa maupun yang ditempuh dengan mendorong partisipasi masyarakat dengan mengacu kepada Rencana Kerja Pemerintah (RKP). 
Sebelum menjadi RKP-Desa maka perlu dilakukan perumusan sejumlah alternatif program yang nantinya menjadi RKP-Desa. Beberapa kegiatan yang dilakukan untuk perumusan RKP-Desa adalah (1) memeriksa perioritas masalah dan kegiatan, meliputi (a) kegiatan pengkajian infomasi permasalahan pada bidang program dan kegiatan indikatif; (b) membuat matriks program kegiatan per sektor/bidang pembangunan 5 tahun; (c) melakukan verifikasi dokumen menurut hasil kajian dusun/RW; (2) menyusun tabel kegiatan untuk RKP-Desa, yang terdiri dari; (a) pengujian prioritas masalah dan kegiatan berdasarkan dokumen RPJM-Desa dengan menggunakan matriks ranking (skoring) berdasarkan kriteria indicator yang baik; (b) pengisian tabel (matriks) kegiatan per bidang pembangunan untuk penyusunan RKP-Desa tahun yang direncanakan;(3) diskusi pleno untuk saling memberikan masukan, terutama melakukan verifikasi dari sumber data/informasi yang ada; (4) penyusunan draf rancangan awal RKP-Desa berdasarkan hasil rapat kerja dan rencana anggaran biaya (RAB) kegiatan-kegiatannya.

\subsection{Evaluasi Program}

Evaluasi program diadakan dengan tujuan untuk mengetahui tingkat keberhasilan program pelatihan kepada kelompok sasaran yaitu aparat desa dan tokoh masyarakat di desa Baumata Utara Kecamatan Taebenu Kabupaten Kupang.

Indikator untuk mengetahui keberhasilan ini adalah:

a. Target peserta pelatihan minimal $75 \%$ telah tercapai. Dari 35 peserta yang ditargetkan jumlah yang pendaftar 30 orang.

b. Target kehadiran peserta minimal $75 \%$ dari peserta yang mendaftar telah tercapai. Dalam kegiatan pelatihan lebih $75 \%$ jumlah peserta yang hadir dari seluruh sesi pelatihan yaitu mencapai 27 peserta.

c. Dalam pelatihan tersedia juklak/juknis berupa makalah yang disiapkan oleh instruktur yang dibagikan kepada para peserta pelatihan.

d. Pelatihan perencanaan berlangsung sesuai dengan dengan rencana yaitu dilaksanakan dalam satu hari yang dimulai dari pukul $08.00 \mathrm{~s} / \mathrm{d}$ pukul 17.00 wita.

\subsection{Evaluasi hasil}

Tujuan dari evaluasi hasil adalah untuk mengetahui tingkat keberhasilan dari kegiatan pelatihan. Dialog interaktif antara peserta dan instruktur yang berlangsung secara intensif menunjukkan bahwa peserta memiliki perhatian yang besar untuk memahami materi yang disampaikan oleh instruktur. Terdapat beberapa pertanyaan yang bersifat substantif dari peserta, antara lain:

a. Peserta mempertanyakan potensi-potensi apa saja yang dimiliki oleh desa yang dapat dijadikan patokan untuk melakukan perencanaan di tingkat pedesaan.

b. Peserta mempertanyakan tentang bagaimana cara atau metode yang efektif untuk merumuskan SWOT dalam bidang perencanaan desa.

c. Peserta juga mempertanyakan tentang bagaimana cara merumuskan alternatif yang terbaik dalam melakukan perencanaan pembangunan di tingkat desa. 
Berdasarkan penilaian tentang evaluasi hasil menunjukkan pelatihan ini berhasil dilaksanakan dengan indikator:

a. $75 \%$ peserta yang hadir mampu memahami dan menganalisis potensi-potensi yang ada di desa Baumata Utara. Para peserta dapat mengungkapkan berbagai potensi ekonomi, sosial, budaya yang ada di desa Baumata Utara.

b. $75 \%$ peserta mampu menjelaskan dan memberikan contoh tentang kekuatankekuatan, kelemahan-kelemahan, ancaman dan peluang program yang diajukan dalam Musrenbang.

c. $75 \%$ peserta dapat merumuskan 2 sampai 3 alternatif program/proyek yang sesuai dengan potensi, permaslahan, dan kebutuhan desa.

\subsection{Evaluasi Akhir}

Evaluasi akhir adalah merupakan penilaian akhir dari kegiatan pelatihan perencanaan. Berdasarkan evaluasi program dan evaluasi hasil yang menunjukkan hasil yang baik, maka disimpulkan bahwa penilaian akhir dari kegiatan pelatihan perencanaan bagi aparat desa Baumata Utara Kecamatan Taebenu Kabupaten Kupang berhasil dengan baik. Penilaian didasarkan kepada indikator-indikator antara lain:

a. Seluruh aparat pemerintah desa yang mengikuti pelatihan dapat melakukan analisis mengenai potensi desa, hal ini didasarkan pada simulasi analisis potensi desa. Aparat desa mampu menunjukkan potensi desa, mampu mengabstraksikan permasalahanpermasalahan dan menjelaskan kebutuhan-kebutuhan pembangunan desa.

b. Seluruh aparat pemerintah desa yang mengikuti pelatihan mampu melaksanakan analisis SWOT rencana program/proyek pembangunan desa. Aparat desa mampu menguraikan indikator-indikator dari setiap dimensi SWOT dan menghubungkan dengan program/proyek pembangunan melalui simulasi.

Aparat desa yang mengikuti pelatihan perencanaan dapat merumuskan berbagai alternatif program/proyek pembangunan desa, hal ini diukur berdasarkan permasalahan dan potensi yang dimiliki oleh desa Baumata Barat Kecamatan Taebenu Kabupaten Kupang.

\section{SIMPULAN}

Berdasarkan uraian tentang pelaksanaan kegiatan pelatihan perencanaan pembangunan bagi aparat desa Baumata Utara Kecamatan Taebenu Kabupaten Kupang, dapat disimpulkan:

1. Pelatihan perencanaan pembangunan desa yang diikuti oleh aparat desa dan tokohtokoh masyarakat dapat memberikan wawasan perencanaan bagi aparat dan tokoh masyarakat sebagai bekal dalam melakukan proses Musrenbang yang merupakan kegiatan rutin bagi aparat dan tokoh masyarakat.

2. Berdasarkan hasil evaluasi yang terdiri dari evaluasi program, dan evaluasi akhir menunjukkan bahwa kegiatan pelatihan berhasil dilaksanakan dengan baik, indikatornya adalah: 
a. Aparat desa mampu melakukan analisis sederhana tentang potensi dan permasalahan pembangunan desa di desa Baumata Utara kecamatan Taebenu kabupaten Kupang.

b. Aparat desa mampu melakukan analisis SWOT tentang perencanaan pembangunan desa di desa Baumata Utara kecamatan Taebenu kabupaten Kupang.

c. Aparat desa mampu merumuskan berbagai alternatif program/proyek pembangunan desa berdasarkan kepentingan masyarakat di desa Baumata Utara kecamatan Taebenu kabupaten Kupang.

\section{UCAPAN TERIMA KASIH}

Ucapan terima kasih yang sebesar-besar disampaikan kepada pemerintah Kabupaten Kupang Provinsi Nusa Tenggara Timur atas izin pelaksanaan kegiatan pelatihan dan dukungan yang diberikan kepada Tim Pengabdian Masyarakat (PPM) Fisip Undana Kupang, semoga kerjasama Pemerintah Kabupaten Kupang dan Fisip Undana senantiasa terjaga dan berlangsung terus dimasa yang akan datang.

\section{REKOMENDASI}

Kegiatan pelatihan perencanaan merupakan kegiatan yang sangat bermanfaat bagi aparat desa karena dengan pelatihan yang diberikan mereka memperoleh kompetensi dibidang perencanaan pembangunan desa. Mengingat waktu yang tersedia untuk pelatihan adalah sangat terbatas maka disaran agar pelatihanpelatihan yang sejenis dialokasikan waktu yang cukup agar praktik dan simulasi perencanaan benar-benar dapat dikuasai oleh aparat desa yang mendapat pelatihan. Selain itu juga diperlukan penambahan materi untuk memperkuat teknis analisis SWOT yaitu teknik Balance Score-card sehingga hubungan antar aspek perencanaan dan penganggaran lebih rasional.

\section{REFERENSI}

Chambers, Robert. (1987). Pembangunan Desa Mulai dari Belakang, Jakrta, LP3ES.

Kartasasmita, Ginanjar. (1997). Administrasi Pembangunan, Perkembangan Pemikiran dan praktiknya di Indonesia, Jakarta, LP3ES.

Maschab, Mashuri. (2013). Politik Pemerintahan Desa di Indonesia, Yogyakarta, PolGov.

Ndraha, Taliziduhu. (1994). Dimensi-dimensi Pemerintahan Desa, Jakarta, Bumi Aksara.

Robbins, Stephen P. (2003). Organization Behavior, Tent Edition, New Jersey, Prentice Hall International Inc.

Syahwier, C.Ahmad. (2011). Membangun Kemandirian Desa, Harian Waspada.

Sjafrizal. (2015). Perencanaan Pembangunan Daerah Dalam Era Otonomi, Jakarta, PT.RajaGrafindo Persada. 
Sofo, Francesco. (1999). Human Resource Development, Perspective, Roles, and Practice Choices, Warriewood, NSW: Business and Professional Publishing.

Spencer, Lyli M, M.Signe Spencer. (1993). Competence at Work: Models for Superior Performance, New York: John Wiley \& Son, Inc.

Sulistio, E.Budi. (2009). Masalah, Prinsip, dan Strategi perencanaan Pembangunan Desa, Lampung, Unila.

Supeno, Wahjudin. (2011). Perencanaan Desa Terpadu, Edisi Revisi, Banda Aceh, Read.

Peraturan Pemerintah (PP) Nomor 72 Tahun 2005 Tentang Pengaturan Desa

Permendagri Nomor 66 Tahun 2007 Tentang Perencanaan Pembangunan Desa 